\title{
Effects of the first-wave COVID-19 pandemic's on emergency urological care in Colombia: A multicenter study.
}

\section{Efectos de la primera ola de la pandemia por COVID 19 en la atención urológica de urgencias en Colombia: Estudio multicéntrico.}

\begin{abstract}
iDDavid Andrés Castañeda-Millán, ${ }^{*}$ Sebastián Rodríguez-Piraquive, ${ }^{2}$ Pedro-Luis Guachetá-Bomba, ${ }^{3}$ David Augusto Cortés-Páez, ${ }^{4}$ iD Juan Pablo Alzáte-Granados, ${ }^{1}$ iDJuan Camiln Álvarez-Restrepo, ${ }^{1}$ Cesar Capera-López, ${ }^{2}$ Marcela Guachetá-Bomba, ${ }^{3}$ Stephani Gómez-Castro, ${ }^{5}$ iD Jorge Forero-Muñoz, ${ }^{5}$ Herney Andrés García-Perdomo. ${ }^{6}$
\end{abstract}

Key words: COVID-19; Pandemics; Urology department, Hospital; Emergencies.

Autor de correspondencia:

* David Andrés Castañeda Millán. Carrera 30 No.

45-03, Facultad de Medicina-Edificio 471, Oficina 107. Bogotá, Colombia. C.P 111321.

Correo electrónico: dacastanedam@unal.edu.co

\section{Abstract}

Introduction: The COVID-19 pandemics has caused millions of deaths worldwide, has increased the demand for in-hospital beds and has affected in-hospital activities of "non-respiratory patients." There is currently no known effect of the pandemic on the emergency urological care in our region. This study aims to estimate the first - wave COVID-19 pandemics effect on emergency urological care in four tertiary Colombian hospitals.

Material and methods: A cross-sectional retrospective multicenter study were made. The emergency urological care activities between April - May 2019 and April - May 2020 were compared. We calculated descriptive statistics and assessed differences during the study periods. We used Stata 13.0.

Results: 1570 patients were included. There was a $22.20 \%$ decrease in the number of patients who visited the emergency room (ER) for urological disease during the pandemic's initial phase. Urolithiasis and urological infectious were the most common reasons for consulting in the ER. The surgical index for patients who required emergency urological care had a increase of $10.74 \%$ (p: 0.0001). There was a decrease of 0.74 days in hospital stay for patients who required urological emergency care in the initial COVID-19 pandemic period.

Conclusions: The COVID-19 pandemic has had a significant impact on emergency and elective urological care worldwide. During the initial phase of this emergency, there was a significant decreased in hospital admission and average hospital stays due to urological emergencies in Colombia, however, the surgical index for critical urological diseases increased by $10.74 \%$. According to the pandemic's dynamics, a greater effect on urological care is expected..

Citación: Castañeda-Millán D. A., Rodríguez-Piraquive S., Guachetá-Bomba P.L., Cortés-Páez D. A., Alzáte-Granados J. P., Álvarez-Restrepo J. C. et al. Effects of the first - wave COVID-19 pandemics on emergency urological care in Colombia: A multicenter study. Rev Mex Urol. 2020;81(5):pp 1-7-

${ }^{1}$ Universidad Nacional de Colombia. Bogotá, Colombia.

${ }^{2}$ Clínica Antioquia, Antioquia, Colombia.

${ }^{3}$ Hospital Universitario del Valle. Cali (Valle del Cauca), Colombia.

${ }^{4}$ Clínica de Occidente, Bogotá, Colombia.

${ }^{5}$ Hospital Occidente de Kennedy, Bogotá, Colombia.

${ }^{6}$ Grupo de investigación UROGIV, Universidad del Valle, Cali, Colombia.

Recibido: 09 de marzo de 2021

Aceptado: 25 de octubre de 2021

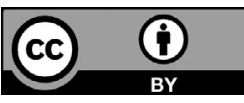


Palabras clave:

COVID-19; pandemia; departamento de urología, hospital; emergencias

\section{Resumen}

Introducción: La pandemia por COVID-19 ha causado millones de fallecimientos alrededor del mundo, ha incrementado la demanda de camas hospitalarias y ha afectado la atención intrahospitalaria de pacientes con patologías "no respiratorias". Actualmente no conocemos el efecto que ha causado la pandemia en la atención urológica de urgencias en nuestra región. Este estudio tiene como objetivo estimar el efecto de la primera ola de la pandemia por COVID-19 en la atención urológica de urgencias en cuatro centros hospitalarios colombianos de alto nivel de complejidad.

Materiales y método: Estudio multicéntrico retrospectivo de corte transversal. Se compararon las atenciones urológicas de urgencias entre el periodo abril - mayo 2019 y abril - mayo 2020. Se calculó la estadística descriptiva y se valoraron diferencias durante los periodos de estudio con el t- test y z - test. El análisis de datos se ejecutó en Stata 13.0.

Resultados: Se incluyeron 1570 pacientes. Hubo una reducción del $22.20 \%$ en la cantidad de pacientes que consultaron al servicio de urgencias por motivos urológicos durante la fase inicial de la pandemia por COVID-19. La urolitiasis y las infecciones urológicas fueron los motivos de consulta más frecuentes para la visita al servicio de urgencias. Hubo un descenso significativo en las consultas por retención urinaria aguda (p: 0.001). El índice quir'úrgico para pacientes que consultaron al servicio de urgencias por patología urológica incrementó en 10.74\% (p: 0.0001). El promedio de estancia hospitalaria disminuyó 0.74 días para los pacientes que requirieron atención urológica de urgencias durante la fase inicial de la pandemia por COVID-19.

Conclusiones: La pandemia por COVID-19 ha afectado de forma significativa la atención urológica ambulatoria y de urgencias alrededor del mundo. Durante la fase inicial de esta pandemia hubo una disminución en la cantidad de pacientes admitidos al servicio de urgencias por patología urológica (incluyendo la retención urinaria aguda) y en su estancia hospitalaria promedio en Colombia, sin embargo, el índice quirúrgico para patología urológica de urgencias aumentó en $10.74 \%$. De acuerdo con la dinámica de la pandemia en nuestra región se espera que el efecto en la atención urológica sea mayor.

\section{Abbreviations:}

SARS-CoV-2: severe acute respiratory syndrome coronavirus-2

COVID-19: Coronavirus-19

ER: Emergency room

IQR: Interquartile range

UTI: Urinary tract infection.

\section{Introduction}

The SARS-CoV-2 pandemic is one of the most shocking events in recent history. Until December 31, 2020, more than 82 million infections and 1,8 million deaths were reported worldwide. $^{(1)}$ In Colombia alone, 1,642,775 cases and 43,213 deaths were registered during 2020 . $^{(2)}$ The vast majority of regions affected by the pandemic have described a saturation in the capacity of in-hospital care and a gene- 
ralized increase in the demand for intensive care unit beds. ${ }^{(3,4)}$ Thus, increasing the need for mitigation measures such as mandatory social distancing, restriction of free mobility and gatherings, and public places closure. ${ }^{(5,6)}$

In this context, healthcare has prioritized its resources for seriously ill respiratory patients. $^{(7)}$ In contrast, other healthcare areas, such as urology, have seen a decrease in their usual in-hospital activity. Multiple international guidelines have proposed care pathways and prioritization schemes for patients with urological pathologies during the COVID-19 pandemic. ${ }^{(8)}$ Since the declaration of a state of a health emergency, diagnostic outpatient services, outpatient consultation, and elective urological surgery have been canceled or transferred to telemedicine care. However, up to this date, the impact that the pandemic has generated on urological emergency care is unknown.

This study aims to estimate the first- wave COVID-19 pandemics effect on emergency urological care in four tertiary hospitals throughout Colombia.

\section{Material and methods}

Design type: A cross-sectional retrospective descriptive multicenter study.

Population and sample: Institutional databases of hospital admissions for urological emergencies in four tertiary centers located in primary regions of Colombia [Bogotá (Cundinamarca), Itagüí (Antioquia), Cali (Valle del Cauca)] during the periods April - May 2019 (period 1) and April - May 2020 (period 2) [initial public health emergency declaration due to the COVID-19 pandemic].

Variables: We analyzed the number of hospital admissions due to urological patholo- gies, reasons for consultation, surgical index, and average time of hospitalization during the study periods.

Statistical analysis: We calculated the t-student test and two proportions z-test to assess differences in the variables evaluated during the study periods. We described the results in frequencies and central tendency measures. We performed the analysis in Stata 13.0.

Ethics: A risk-free study; according to Colombian regulations (Resolution 8430 of 1993) informed consent was not required. The principles established in the Declaration of Helsinki were respected.

\section{Results}

We included 1,570 patients (542 from Bogotá, 778 from Itagüí, and 250 from Cali). In the first period, 883 patients visited the ER with a urological concern, and 687 in the second period. The study group's average age was 49.30 years, with a median of 48 years (IQR: 33-64). Approximately $70 \%$ of participants (n: 1094) were men, while $30.32 \%$ (n: 476) were women; for period 1, the distribution was $71.35 \%$ men and $28.65 \%$ women, while for period 2 , the distribution was $67.54 \%$ men and $32.46 \%$ women.

In general, there was a $22.20 \%$ decrease in the number of patients who visited the ER for urological disease during the initial phase of the pandemic compared to the same period of the previous year. In Bogotá, the reduction was $26.84 \%$, while in Itagüí and Cali, the decline was $7.43 \%$ and $49.40 \%$. Urolithiasis and infectious conditions were the most common urological reasons for consulting to the ER; there was a significant decrease in ER visits caused by acute urinary retention (p: 0.001) (Table 1). 
Tabla 1. Reasons for emergent urological consultation in four Colombian hospitals

\begin{tabular}{|l|c|c|c|}
\hline Reasons for consultation & Period 1\%(n) & Period 2\% (n) & p-value \\
\hline Renal colic / Urolithiasis & $41.34(365)$ & $50.65(348)$ & 0.007 \\
\hline Urologic infections & $21.63(191)$ & $19.36(133)$ & 0.6 \\
\hline $\begin{array}{l}\text { (epididymo-orchitis, } \\
\text { Fournier's Gangrene, } \\
\text { scotal abscess, UTI) }\end{array}$ & $11.44(101)$ & $8(55)$ & 0.54 \\
\hline $\begin{array}{l}\text { Others (priapism, penile } \\
\text { fracture, phimosis) }\end{array}$ & $11.09(98)$ & $10.04(69)$ & 0.001 \\
\hline Hematuria & $10.19(90)$ & $6.55(45)$ & 0.8 \\
\hline Acute urinary retention & $3.06(27)$ & $3.64(25)$ & 0.75 \\
\hline Urological trauma & $1.24(11)$ & $1.75(12)$ & 0.8 \\
\hline $\begin{array}{l}\text { Acute scrotum/ } \\
\text { Testicular torsion }\end{array}$ & & & 0.8 \\
\hline
\end{tabular}

Period 1: April - May 2019, Period 2: April - May 2020 (initial public health emergency declaration due to the COVID 19 pandemic). UTI: Urinary tract infection.

The surgical index (proportion of individuals who required surgical management) for patients who visited the ER for urological diseases had a general increase of $10.74 \%$, ranging from $26.38 \%$ (n: 233 ) in period 1 to $37.12 \%$ (n: 255) in period 2 (p: 0.0001). In Bogotá and Itagüí there was an increase of $14.86 \%$ (p: 0.04 ) and $13.43 \%$ (p: 0.0001 ) respectively, while in Cali decreased by $1.08 \%$ (p: 0.86 ).

The medical index (proportion of patients hospitalized for urological pathology for non-surgical management) had a general decrease of $10.73 \%$ [period 1: $73.61 \%$ (n: 650 ) versus period 2: $62.88 \%$ (n: 432)] (p: 0.001). In Bogotá and Itagüí there was a decrease of 14.85\% (p: 0.0029) and $13.44 \%$ (p: 0.001) respectively, while in Cali there was an increase of 1.07\% (p: 0.8).

There was a decrease of 0.74 days in hospital stay for patients who required urological emergency care in the initial period of the COVID-19 pandemic in Colombia, compared to the previous year. Accordingly, in period 1, the average time of hospitalization was 3.33 days/patient, while in period 2, it was 2.59 days/patient. In Bogotá and Itagüí, there was a decrease of 1.16 days and 0.66 days in average hospital stay, respectively, while in Cali, there was an increase of 0.52 days (Table 2).

Table 2. Average hospital stays for patients admitted for emergent urological diseases

\begin{tabular}{|c|c|c|c|c|}
\hline City & Period 1. & Period 2. & Change & $p$-value \\
\hline & & & & 0.007 \\
\hline Bogotá & 3.88 days & 2.72 days & -1.16 days & 0.009 \\
\hline Itagüí & 2.86 days & 2.20 days & -0.66 days & 0.12 \\
\hline Cali & 3.44 days & 3.96 days & +0.52 days & 0.39 \\
\hline Total & 3.33 days & 2.59 days & -0.74 days & \\
\hline
\end{tabular}

Period 1: April - May 2019, Period 2: April - May 2020 (initial public health emergency declaration due to the COVID 19 pandemic). 


\section{Discussion}

The SARS-CoV-2 pandemic has not only had an impact on the care of symptomatic respiratory patients. The prioritization of hospital care for seriously ill respiratory patients, high hospital occupancy, and cross-contamination risk forced a transformation in the care for "non-respiratory" patients. ${ }^{(9)}$

Pinar et al., ${ }^{(10)}$ described an overall decrease in urological surgical activities (55\%), urological emergencies (44\%), and urooncological surgeries (31\%) in France. They also described a reduction in scheduled outpatient urological surgery of $84 \%$, and kidney transplantation of $92 \%$ during the SARS-CoV-2 pandemic. Up to two-thirds of major urological surgery could be safely postponed in Italy until the crisis generated by the SARS-CoV-2 pandemic had resolved. ${ }^{(11)}$ There was an overall decrease of $55 \%$ in urological emergency consultation. ${ }^{(12)}$ In Germany, $77.9 \%$ of urologists stated that they had more significant restrictions in their surgical practice, and $9.4 \%$ had a total cessation of their surgical activity due to the SARSCoV-2 pandemic. ${ }^{(13)}$ In Portugal, Madanelo et al., ${ }^{(14)}$ described an overall decrease of $46.4 \%$ in urological ER consultation between March and april/2019 compared to March-april/2020.

A survey conducted among 846 Latin American urologists showed that $60.9 \%$ currently perform only emergency surgical procedures. In contrast, $49.4 \%$ state that their outpatient clinic service is closed, and $48.2 \%$ carry out their consultations with telemedicine. ${ }^{(15)}$ Worldwide, a delay more significant than eight weeks secondary to the SARS-CoV-2 pandemic has been described for $28 \%$ of urological consultations, $30 \%$ of urological outpatient diagnostic studies, and $31 \%$ of elective surgeries. ${ }^{(16)}$ In
Colombia, a $56.45 \%$ decrease in kidney transplants performed during the initial phase of the public health emergency declaration due to the SARS-CoV-2 pandemic has been reported. ${ }^{(17)}$

The results obtained here are similar to other international experiences. They show that the SARS-CoV-2 pandemic and the public health strategies implemented to mitigate the pandemic's effect translate into a decrease in the volume of patients who visit the emergency room for urological diseases. Besides, a reduction in hospital stay length and an increase in the urological surgical index might be explained by a delayed consultation. All these events are undoubtedly related to the rationing of the physical and human resources required in critical moments of the pandemic. It is essential to highlight the increase in consultation for urolithiasis seen during the initial phase of the pandemic (a fact that might explain the rise in surgical procedures), and the significant decrease in the consultation for acute urinary retention. This rise could also connect, in some way, to the measures established by local governments during the initial phase of the pandemic (limited mobility due to quarantining at home, restriction on the sale of alcoholic beverages, the prohibition of social events and meetings, etc.).

Our study's dynamics are similar to those described by Motterle et al., ${ }^{(18)}$ in Italy. Urological emergency care's common denominator was decreased consultations and an increased proportion of surgical procedures performed ( $28.6 \%$ in 2019 versus $33.6 \%$ in 2020 during the COVID-19 pandemic).

Despite the limitations derived from the type of study, sample size, the temporal effect of the pandemic, and its variability in the different regions of the country, this study can characterize some initial exploratory results 
and constitutes the first experience described in Latin America on the effect of the pandemic on emergency urological care. Noting that a pandemic's peak had not been reached at the time of data analysis and consolidation (Figure 1), and that additional peaks are expected in our country, the impact on the Colombian urological services is expected to be exponentially greater.

Figura 1. Daily reported cases

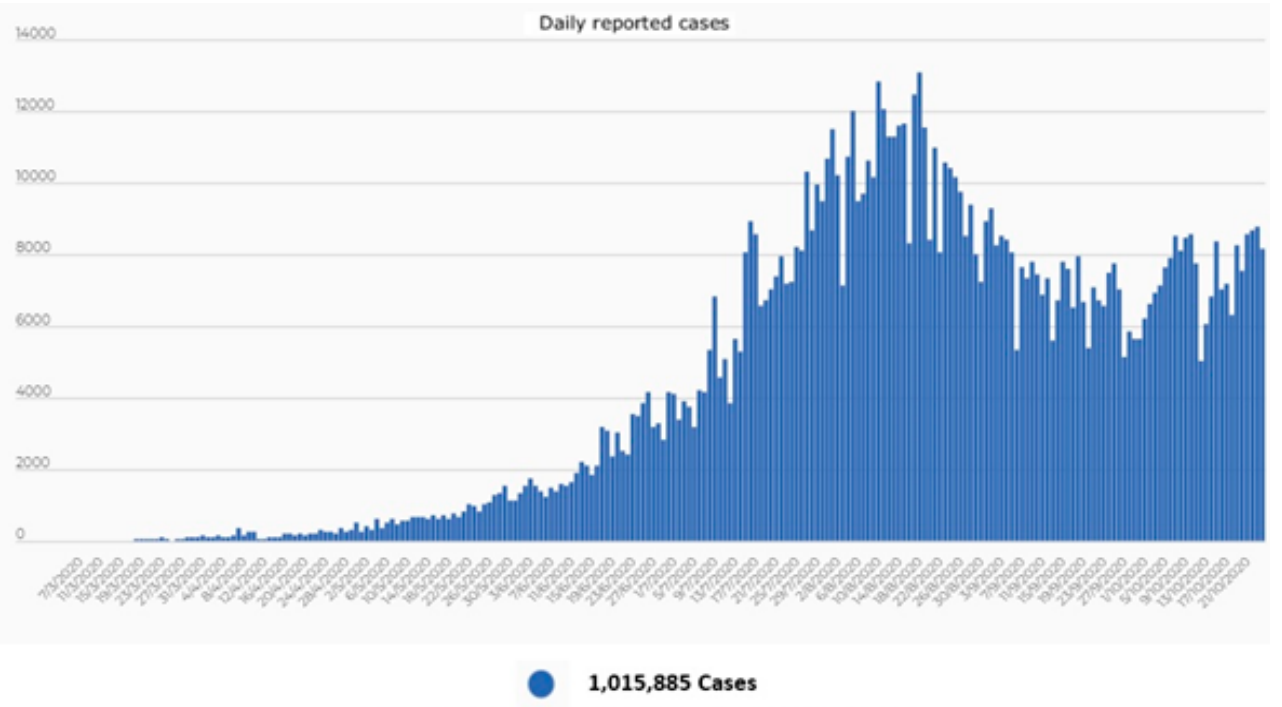

Date of first reported case in Colombia: March 6th, 2020

Date of start of quarantine in Colombia: March 25th,2020

The behavior of new cases due to COVID 19 in Colombia. Taken and translated from https://www.ins.gov.co/Noticias/ Paginas/coronavirus-casos.aspx. ${ }^{(2)}$

\section{Conclusions}

The SARS-CoV-2 pandemic has had a significant impact on emergency and elective urological care around the world. During the initial phase of this emergency, there was a decrease of $22 \%$ in hospital admissions due to urological emergencies in Colombia. The surgical index for critical urological diseases increased by $10.74 \%$, and the average hospital stays decreased 0.74 days. There was a significant increase in the emergency consultation for urolithiasis and decreased consultation for acute urinary retention. According to the pandemic's dynamics, we expect an increase in the impact on elective and emergent urological care in our country.

\section{Conflict of interest}

None declared. 
Efectos de la primera ola de la pandemia por COVID 19 en la atención urológica...Castañeda-Millán D.A., et al.

\section{References}

1. World Health Organization. WHO Coronavirus (COVID-19) Dashboard. 2020. Available from: https://covid19.who.int/

2. Instituto Nacional de Salud. COVID-19 Colombia Reporte 31-12-2020. COVID-19 en Colombia. 2020. Available from: https://www. ins.gov.co/Noticias/Paginas/Coronavirus.aspx

3. Shoukat A, Wells CR, Langley JM, Singer BH, Galvani AP, Moghadas SM. Projecting demand for critical care beds during COVID-19 outbreaks in Canada. CMAJ. 2020;192(19):E489-96. doi: 10.1503/cmaj.200457

4. Li R, Rivers C, Tan Q, Murray MB, Toner E, Lipsitch M. Estimated Demand for US Hospital Inpatient and Intensive Care Unit Beds for Patients With COVID-19 Based on Comparisons With Wuhan and Guangzhou, China. JAMA Network Open. 2020;3(5):e208297. doi: 10.1001/jamanetworkopen.2020.8297

5. Wilder-Smith A, Freedman DO. Isolation, quarantine, social distancing and community containment: pivotal role for old-style public health measures in the novel coronavirus (2019-nCoV) outbreak. J Travel Med. 2020;27(2):taaa020. doi: 10.1093/jtm/taaa020

6. Rothan HA, Byrareddy SN. The epidemiology and pathogenesis of coronavirus disease (COVID-19) outbreak. Journal of Autoimmunity. 2020;109:102433. doi: 10.1016/j.jaut.2020.102433

7. Leclerc T, Donat N, Donat A, Pasquier P, Libert N, Schaeffer E, et al. Prioritisation of ICU treatments for critically ill patients in a COVID-19 pandemic with scarce resources. Anaesth Crit Care Pain Med. 2020;39(3):333-9. doi: 10.1016/j.accpm.2020.05.008

8. Amparore D, Campi R, Checcucci E, Sessa F, Pecoraro A, Minervini A, et al. Forecasting the
Future of Urology Practice: A Comprehensive Review of the Recommendations by International and European Associations on Priority Procedures During the COVID-19 Pandemic. Eur Urol Focus. 2020;6(5):1032-48. doi: 10.1016/j.euf.2020.05.007

9. Rockwell KL, Gilroy AS. Incorporating telemedicine as part of COVID-19 outbreak response systems. Am J Manag Care. 2020;26(4):147-8. doi: 10.37765/ ajmc.2020.42784

10. Pinar U, Anract J, Duquesne I, Dariane C, Chartier-Kastler E, Cussenot O, et al. [Impact of the COVID-19 pandemic on surgical activity within academic urological departments in Paris]. Prog Urol. 2020;30(8-9):439-47. doi: 10.1016/j.purol.2020.05.001

11. Campi R, Amparore D, Capitanio U, Checcucci E, Salonia A, Fiori C, et al. Assessing the Burden of Nondeferrable Major Uro-oncologic Surgery to Guide Prioritisation Strategies During the COVID-19 Pandemic: Insights from Three Italian High-volume Referral Centres. Eur Urol. 2020;78(1):11-5. doi: 10.1016/j. eururo.2020.03.054

12. Novara G, Bartoletti R, Crestani A, De Nunzio C, Durante J, Gregori A, et al. Impact of the COVID-19 pandemic on urological practice in emergency departments in Italy. BJU International. 2020;126(2):245-7. doi: 10.1111/bju.15107

13. Paffenholz P, Peine A, Fischer N, Hellmich M, Pfister D, Heidenreich A, et al. Impact of the COVID-19 Pandemic on Urologists in Germany. Eur Urol Focus. 2020;6(5):1111-9. doi: 10.1016/j.euf.2020.06.001

14. Madanelo M, Ferreira C, Nunes-Carneiro D, Pinto A, Rocha MA, Correia J, et al. The impact of the coronavirus disease 2019 pandemic on the utilisation of emergency urological services. 


\section{Efectos de la primera ola de la pandemia por COVID 19 en la atención urológica...Castañeda-Millán D.A., et al.}

BJU international. 2020;126(2):256-8. doi: 10.1111/bju.15109

15. Autrán-Gómez AM, Tobia I, Molina RC, Covarrubias FR, Benzing F, Maruccia S, et al. Exploring Urological Experience in the COVID-19 Outbreak: American Confederation of Urology (CAU) Survey. Int Braz J Urol. 2020;46(Suppl 1):156-64. doi: 10.1590/S16775538.IBJU.2020.S119

16. Teoh JY-C, Ong WLK, Gonzalez-Padilla D, Castellani D, Dubin JM, Esperto F, et al. A Global Survey on the Impact of COVID-19 on Urological Services. Eur Urol. 2020;78(2):26575. doi: 10.1016/j.eururo.2020.05.025
17. Castañeda-Millán DA, Pardo-Acuña J, CortésPáez DA, Autran-Gómez AM, Pérez-Pachón AM, Niño-Ramírez $L$, et al. Donación y trasplante de órganos en medio de la pandemia COVID-19: Consecuencias y retos para un país emergente. Revista Urología Colombiana / Colombian Urology Journal. 2020;29(3):16873. doi: $10.1055 / \mathrm{s}-0040-1715637$

18. Motterle G, Morlacco A, Iafrate M, Bianco M, Federa G, Xhafka O, et al. The impact of COVID-19 pandemic on urological emergencies: a single-center experience. World J Urol. 2020 May 23;1-5. doi: 10.1007/s00345-020-03264-2 